ISSN: 2302-8556

\title{
Pengaruh Implementasi SIMDA, Kinerja Aparatur Pemerintah Daerah dan Penerapan SAP Terhadap Kualitas LKPD Lombok Tengah
}

\author{
Rahmatia Azzindani ${ }^{1}$ \\ Endar Pituringsih ${ }^{2}$ \\ M. Irwan ${ }^{3}$
}

${ }^{1,2,3}$ Fakultas Ekonomi dan Bisnis Universitas Mataram (Unram), NTB, Indonesia e-mail: rahmatiaazzindani@gmail.com

\begin{abstract}
ABSTRAK
Penelitian bertujuan untuk membuktikan secara empiris pengaruh implementasi SIMDA terhadap kualitas LKPD, pengaruh kinerja aparatur pemerintah daerah terhadap kualitas LKPD, dan pengaruh penerapan SAP terhadap kualitas LKPD. Sumber data pada penelitian menggunakan kuesioner yang disebar pada 32 OPD di Kabupaten Lombok Tengah. Hasil penelitian dari $\mathrm{H}_{1}$ Dan $\mathrm{H}_{2}$ untuk variabel implementasi SIMDA $\left(\mathrm{X}_{1}\right)$ dan $\left(\mathrm{X}_{2}\right)$ menunjukkan bahwa variabel implementasi SIMDA berpengaruh secara signifikan terhadap kualitas LKPD dan nilai $t_{\text {hitung positif }}$ menunjukkan bahwa implementasi SIMDA memiliki hubungan yang searah dengan kualitas LKPD. Serta hasil penelitian LKPD itian dari pengujian hipotesis ketiga $\left(\mathrm{H}_{3}\right)$ untuk variabel penerapan SAP $\left(\mathrm{X}_{3}\right)$ menunjukkan bahwa variabel penerapan SAP tidak memiliki pengaruh secara signifikan terhadap kualitas LKPD dan nilai $t_{\text {hitung }}$ positif menunjukkan bahwa penerapan SAP memiliki hubungan yang searah dengan kualitas LKPD.

Kata kunci: Implementasi SIMDA, Kinerja Aparatur Pemerintah Daerah, Penerapan SAP,
\end{abstract} Kualitas LKPD

\begin{abstract}
The study aims to prove empirically the effect of the implementation of SIMDA on the quality of LKPD, the influence of the performance of regional government officials on the quality LKPD, and the SAP on the quality of LKPD. Sources of data in the study used a questionnaire distributed to $32 \mathrm{ODP} s$ in Central Lombok Regency. The results of $\left(H_{1}\right)$ and $\left(H_{2}\right)$ for the implementation of SIMDA $\left(X_{1}\right)$ and $\left(X_{2}\right)$ indicate that the variable implementation of SIMDA has a significant effect on the quality of LKPD and a positive t-value indicates that the implementation of SIMDA has a relationship in line with the quality of LKPD. As well as the results of research from the testing of the third hypothesis $\left(H_{3}\right)$ for the variable application of $S A P\left(X_{3}\right)$ shows that the application of SAP does not have a significant effect on the quality of LKPD and t-value positively indicates that the application of SAP has a relationship which is in line with the quality of LKPD.

Keywords: Implementation of SIMDA, Performance of Local Government Apparatus, Application of SAP, Quality of LKPD.
\end{abstract}

\section{PENDAHULUAN}

Pemerintah daerah dalam rangka mengoptimalisasi manejemen daerah yang sekaligus berperan sebagai Badan Pengawas Keuangan dan Pembangunan (BPKP) telah mengembangkan aplikasi berbasis komputer berupa Sistem Informasi Manajemen Daerah yang dikenal dengan SIMDA (Ole, 2014) yang 
bertujuan untuk dapat mewujudkan laporan keuangan yang berkualitas. Hal ini didukung oleh penelitian yang dilakukan oleh: Xu dan Lu (2003), Salehi et al. (2010), Grande et al. (2011), Ole (2014), serta Kamal dan Noermansyah (2015). Implemetasi SIMDA berlandaskan pada teori Technology Acceptance Model (TAM) yang beranggapan bahwa para pengguna selalu mempertimbangkan manfaat dari implementasi sistem informasi tersebut. Unsur kegunaan (usefulness) dan kemudahan penggunaan (ease of use) menjadi pertimbangan, karena dengan diterapkannya sistem informasi dapat memengaruhi kinerja seseorang dalam melaksanakan tugas dan pekerjaannya (Jogiyanto, 2007:114). Sedangkan untuk menggambarkan kualitas informasi keuangan, khususnya yang disajikan dalam Laporan Keuangan Pemerintah Daerah (LKPD) belum sepenuhnya memiliki karakteristik kualitatif laporan keuangan yang sesuai dengan Standar Akuntansi Publik (SAP), sehingga pemahaman terhadap SAP yang diterapkan dapat meningkatkan kualitas laporan keuangan yang disajikan. SAP merupakan persyaratan yang memiliki kekuatan hukum guna meningkatkan kualitas LKPD (Nugraeni dan Budiantara, 2015; dan Oktarina, dkk. 2016). Menurut SAP sesuai Peraturan Pemerintah Nomor 24 Tahun 2005 sebagaimana telah diubah dengan Peraturan Pemerintah Nomor 71 Tahun 2010, terdapat hubungan terkait antara SAP dan Kualitas LKPD. Dalam SAP dijelaskan bahwa laporan keuangan berkualitas itu harus memenuhi karakteristik kualitas informasi berikut: relevan, andal, dapat dibandingkan, dan dapat dipahami. Hal ini dilandasi oleh Teori Kegunaan Keputusan yang menunjukkan bahwa laporan keuangan yang disajikan harus memenuhi karakteristik-karakteristik tersebut. 
LKPD dapat dikatakan berkualitas apabila laporan keuangan yang disajikan setiap tahunnya mendapatkan penilaian berupa opini Wajar Tanpa Pengecualian (WTP) dari Badan Pengawas Keuangan (BPK). Sebagaimana yang telah diatur di dalam Undang-Undang Nomor 15 Tahun 2004 tentang Pemeriksaan Pengelolaan dan Tanggung Jawab Keuangan Negara, terdapat empat opini yang diberikan oleh BPK yaitu: Wajar Tanpa Pengecualian (WTP), Wajar Dengan Pengecualian (WDP), Tidak Wajar (TW), dan Pernyataan Menolak Memberi Opini. Berdasarkan hal tersebut, teori keagenan digambarkan melalui hubungan antara pengelola keuangan dengan atasannya. Pengelola keuangan yang diangkat atau dipilih oleh atasannya untuk untuk melakukan pengelolaan keuangan, bertanggung jawab untuk menyusun laporan pertanggungjawaban keuangan dalam rangka akuntabilitas publik. Mereka yang dipilih oleh atasannya artinya dipercaya mampu melaksanakan tugas yang telah diamanahkan, sehingga dapat menjadi ajang pembuktian (self actualization) bagi para pengelola keuangan (agents) tersebut untuk membuktikan bahwa mereka adalah orang yang tepat untuk melakukan pekerjaan tersebut (Runtuwene, dkk., 2017). Motivasi tersebut dapat menjadi pendorong bagi para pengelola keuangan tersebut untuk menghasilkan laporan keuangan yang akuntabel, yaitu menunjukkan bahwa mereka telah mampu menjalankan amanah yang diberikan atasannya dengan baik. Terlebih lagi menjadi suatu kepuasan bagi para pengelola keuangan tersebut jika hasil pekerjaan yakni laporan keuangan tersebut mendapat reward dari BPK berupa opini WDP bahkan WTP (esteem needs). Opini BPK seolah menjadi tolak ukur kinerja pengelolaan keuangan selama satu periode tahun tersebut. Jika opini 
yang diperoleh memuaskan artinya mereka telah melaksanakan tugas dan tanggung jawabnya dengan baik, sehingga secara tidak langsung hal tersebut menjadi motivasi bagi setiap pengelola keuangan di tingkat Organisasi Perangkat Daerah (OPD) untuk terus meningkatkan kinerjanya guna menghasilkan laporan pertanggungjawaban keuangan yang lebih berkualitas.

Fenomena yang diangkat dalam penelitian ini diperoleh dari survei lapangan pada OPD di Kabupaten Lombok Tengah. Dengan diterapkannya SIMDA pada OPD di Kabupaten Lombok Tengah memiliki dampak positif dalam kualitas LKPD Kabupaten Lombok Tengah, yang awalnya berstatus WDP pada tahun 2011 menjadi Wajar Tanpa Pengecualian pada tahun 2015 (BPK RI Perwakilan NTB, 2016). Aplikasi SIMDA dikembangkan oleh BPKP guna membantu pengelolaan keuangan daerah di tingkat OPD sebagai entitas akuntansi, serta diharapkan dapat memberikan manfaat lebih kepada pemerinah daerah dalam melaksanakan pengelolaan keuangan daerah. Namun, berdasarkan pengamatan awal ditemukan bahwa: SIMDA belum sepenuhnya digunakan secara optimal yang menyebabkan implementasi SIMDA oleh OPD belum dapat membantu mencapai tujuan secara maksimal, kurangnya kesiapan OPD menerima dan mengaplikasikan SIMDA untuk melakukan prosedur akuntansi, belum adanya kepastian tentang aplikasi SIMDA yang dijadikan standar dalam prosedur akuntansi sehingga menyebabkan masih beragamnya bentuk laporan keuangan yang dihasilkan oleh OPD, serta kemampuan penguasaan dalam pengoperasian SIMDA yang belum merata di setiap OPD.

Penelitian ini merupakan hasil olahan dengan mengacu pada penelitian yang 
dilakukan oleh Ole (2014), Ramadhan dan Rahayu (2015), serta Oktarina, dkk. (2016), di mana penelitian ini dilakukan karena dari penelitian-penelitian terdahulu yang menjadi bahan acuan melakukan penelitian pada sisi kualitas aparatur pemerintah daerah mengemukakan bahwa kualitas aparatur pemerintah daerah sangat memengaruhi kualitas laporan keuangaan dikarenakan dengan adanya peningkatan kualitas dari aparatur pemerintah daerah akan menghasilkan laporan keuangan yang berkualitas, begitu pula sebaliknya dengan adanya penurunan kualitas dari aparatur pemerintah daerah akan menghasilkan laporan keuangan yang kurang berkulitas. Sehingga penelitian ini ingin menguji dan membuktikan secara empiris di sisi lain yaitu kinerja aparatur pemerintah daerah yang dapat memengaruhi kualitas laporan keuangan ataukah tidak. Kinerja yaitu prestasi kerja yang merupakan hasil kerja yang dicapai oleh seorang pegawai dalam melaksanakan fungsinya sesuai dengan tanggung jawab yang diberikan kepadanya (Nurlaila, 2010:71). Oleh karena itu, hal tersebut merupakan kebaruan dari penelitian ini (gap research).

Berdasarkan latar belakang di atas, maka dapat ditentukan rumusan masalah dalam penelitian ini, antara lain: 1. Apakah implementasi SIMDA berpengaruh terhadap kualitas LKPD? 2. Apakah kinerja aparatur pemerintah daerah berpengaruh terhadap kualitas LKPD? 3. Apakah penerapan SAP berpengaruh terhadap kualitas LKPD?

Berdasarkan rumusan masalah di atas, maka tujuan dalam penelitian ini adalah untuk mengetahui dan membuktikan secara empiris: pengaruh implementasi SIMDA terhadap kualitas LKPD, pengaruh kinerja aparatur 
pemerintah daerah terhadap kualitas LKPD, dan pengaruh penerapan SAP terhadap kualitas LKPD.

Adapun Grand Theory yang mendasari penelitian ini, yaitu: Teori Technology Acceptance Model (TAM), Teori Keagenan, dan Teori Kegunaan Keputusan. Teori TAM diadaptasi dari Theory of Reasoned Action yang dikembangkan oleh Davis (1989) dengan menambahkan dua unsur utama, yaitu: kegunaan (usefulness) dan kemudahan penggunaan (perceived ease of use). Kedua unsur ini menjadi pertimbangan bahwa dengan menerapkan sistem informasi dapat mempengaruhi kinerja seseorang dalam melaksanakan tugas dan pekerjaannya (Jogiyanto, 2007:114). Sehingga dalam implementasi SIMDA unsur kegunaan (usefulness) dapat terpenuhi karena aplikasi SIMDA merupakan sistem berbasis aplikasi teknologi yang dikembangkan guna mencapai akuntabilitas bagi pemerintah daerah pada entitas akuntansi (OPD). Aplikasi ini dapat membantu pemerintah daerah mulai dari penyusunan perencanaan dan penganggaran, pelaksanaan dan penatausahaan APBD hingga pertanggungjawaban APBD. Begitu pula dengan unsur kemudahan penggunaan (ease of use) karena fitur-fitur dalam aplikasi SIMDA yang sederhana sehingga mudah dimengerti dan dipelajari. Transaksi keuangan pemerintah daerah sehari-hari dapat secara otomatis dihasilkan. Dengan demikian, dapat dikatakan aplikasi SIMDA merupakan sistem yang terintegrasi secara menyeluruh dan mampu menghasilkan informasi yang handal dan relevan sehingga mampu memberi output laporan keuangan yang berkualitas.

Teori Keagenan secara umum dalam pengujian ini terlihat melalui hubungan 
antara pengelola keuangan dengan atasannya, di mana pengelola keuangan yang diangkat atau dipilih oleh atasannya untuk melakukan tugas pengelolaan keuangan. Hubungan keagenan semakin terlihat pada saat seseorang yang telah diangkat atau dipilih untuk melaksanakan suatu tugas, bisa saja suatu saat dipromosi atau dinonaktifkan atau dimutasi ke bidang pekerjaan lainnya. Sehingga menjadi suatu hal yang penting bagi para pengelola keuangan tersebut untuk terus meningkatkan kinerjanya guna memeroleh output yang baik atas pekerjaannya. Mardiasmo (2009:20) menyatakan bahwa akuntabilitas publik adalah kewajiban pihak pemegang amanah (agent) untuk memberikan pertanggung-jawaban, menyajikan, melaporkan, dan mengungkapkan segala aktivitas dan kegiatan yang menjadi tanggungjawabnya kepada pihak pemberi amanah (principal) yang memiliki hak dan kewenangan untuk meminta pertanggung-jawaban tersebut. Masalah keagenan muncul ketika agent cenderung memaksimalkan self interest-nya dan kewenangannya yang dimulai dari proses penganggaran, pembuatan keputusan-keputusan, sampai dengan melaporkan dan menyajikan laporan keuangan yang sewajar-wajarnya untuk memperlihatkan bahwa kinerja mereka selama ini telah baik, serta untuk mengamankan posisinya di mata principal (Ahsani, 2015).

Teori kegunaan keputusan yang dikemukakan oleh Belkaoui (dalam Harahap, 2009:154) bahwa informasi akuntansi menjadi referensi dari penyusunan rerangka konseptual Financial Accounting Standard Boards (FASB), yaitu Statement of Financial Accounting Concepts (SFAC) yang berlaku di Amerika Serikat. Pada tahap awal, teori ini dikenal dengan nama lain yaitu a theory of 
accounting to investors. Standar akuntansi yang ada dapat memberi pedoman bagi para pengelola keuangan dalam melaksanakan pekerjaannya dan mendukung dalam penyajian informasi posisi keuangan yang dapat dipercaya kebenarannya dan memiliki daya banding. Informasi yang dapat dipercaya kebenarannya akan dianggap berkualitas (berguna) bagi pemakai maupun para pengambil keputusan dalam pengambilan keputusan.

Secara sistematis rerangka konseptual penelitian ini dapat dilihat pada Gambar 1 sebagai berikut:

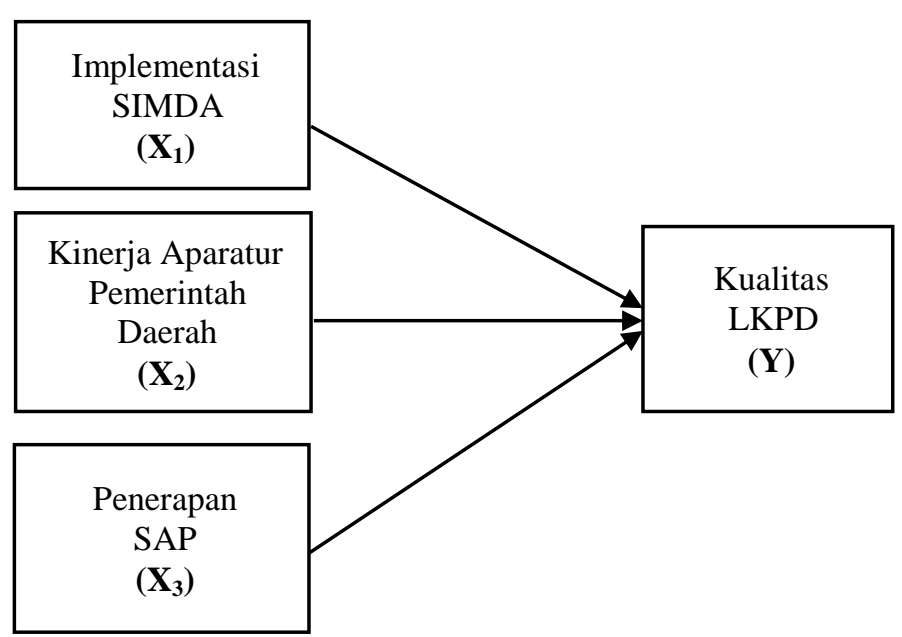

Sumber: data diolah, 2019

\section{Gambar 1. Rerangka Konseptual}

Dengan diterapkannya SIMDA pada OPD di Kabupaten Lombok Tengah memiliki dampak positif dalam kualitas LKPD Kabupaten Lombok Tengah, yang awalnya berstatus WDP pada tahun 2011 menjadi WTP pada tahun 2015 (BPK RI Perwakilan NTB, 2016). Dalam implementasi SIMDA, terdapat dua unsur dari teori TAM yang digunakan, yaitu: unsur kegunaan (usefulness), dan unsur kemudahan penggunaan (ease of use). Unsur kegunaan (usefulness) dapat terpenuhi karena aplikasi SIMDA merupakan sistem berbasis aplikasi teknologi 
yang dikembangkan guna mencapai akuntabilitas bagi pemerintah daerah baik pada entitas akuntansi (OPD). Sedangkan pada unsur kemudahan penggunaan (ease of use) karena fitur-fitur dalam aplikasi SIMDA yang sederhana, sehingga mudah dimengerti dan dipelajari. Transaksi keuangan pemerintah daerah seharihari dapat secara otomatis dihasilkan. Dengan demikian, dapat dikatakan aplikasi SIMDA merupakan sistem yang terintegrasi secara menyeluruh dan mampu menghasilkan informasi yang handal dan relevan sehingga mampu memberi output laporan keuangan yang berkualitas. Hal ini didukung oleh penelitian yang dilakukan Xu dan Lu (2003), Salehi et al. (2010), Grande et al. (2011), Ole (2014), serta Kamal dan Noermansyah (2015) sehingga dapat disimpulkan bahwa implementasi SIMDA berpengaruh positif terhadap kualitas LKPD dan hipotesis dapat dirumuskan sebagai berikut:

$\mathrm{H}_{1}$ : Implementasi SIMDA berpengaruh positif terhadap kualitas LKPD.

Aparatur pemerintah daerah yang profesional dibutuhkan oleh pemerintah daerah dalam menjalankan fungsi pemerintahan yang akan melaksanakan tugas pokok dan fungsinya secara tuntas. Aparatur pemerintah daerah yang memiliki kinerja yang baik di bidang keuangan dapat menyusun LKPD sesuai SAP serta disusun memenuhi kualifikasi informasi yang useful untuk menghasilkan LKPD yang berkualitas. Hal ini didukung oleh penelitian yang dilakukan Ramadhan dan Rahayu (2015), serta Oktarina, dkk. (2016) sehingga dapat disimpulkan bahwa kinerja aparatur pemerintah daerah berpengaruh positif terhadap kualitas LKPD dan hipotesis dapat dirumuskan sebagai berikut:

$\mathrm{H}_{2}$ : Kinerja aparatur pemerintah daerah berpengaruh positif terhadap kualitas LKPD. 
Penerapan SAP dilakukan agar LKPD yang dihasilkan pemerintah daerah dapat diperbandingkan dan adanya kesamaan persepsi, serta pemahaman antara penyaji laporan keuangan, penguna laporan keuangan maupun pengawas laporan keuangan (Mardiasmo, 2002:167). Dalam teori kegunaan keputusan menunjukkan bahwa LKPD yang disajikan harus memenuhi karakteristik kualitas informasi. Unsur kualitas laporan keuangan seperti relevan dan reliabel harus terpenuhi dalam suatu laporan keuangan, sehingga laporan keuangan yang disajikan diyakini berkualitas dan dapat digunakan dalam pengambilan keputusan. Hal tersebut sesuai dengan SAP yang diatur dalam Peraturan Pemerintah Nomor 71 Tahun 2010 bahwa laporan keuangan pemerintah daerah harus memenuhi karakteristik kualitas laporan keuangan yakni relevan, andal, dapat dibandingkan dan dapat dipahami sehingga dengan memenuhi karakteristik tersebut, laporan keuangan pemerintah daerah semakin berkualitas atau berguna bagi pemakai dan para pengambil keputusan. Penelitan yang dilakukan oleh Nugraeni dan Budiantara (2015) menyatakan bahwa penerapan SAP berpengaruh positif terhadap kualitas informasi keuangan pemerintah. Hasil penelitian ini didukung oleh penelitian Sari (2013), Ahsani (2015), Ramadhan dan Rahayu (2015), Oktarina, dkk. (2016), serta Yusniyar, dkk. (2016), sehingga dapat disimpulkan bahwa penerapan SAP berpengaruh positif terhadap kualitas LKPD dan hipotesis dapat dirumuskan sebagai berikut:

$\mathrm{H}_{3}$ : Penerapan SAP berpengaruh positif terhadap kualitas LKPD.

\section{METODE PENELITIAN}


Jenis penelitian yang digunakan yaitu eksplanatori dengan pendekatan kuantitatif. Adapun penelitian eksplanatori menurut Sugiyono (2016:21) adalah penelitian yang menjelaskan hubungan kausal antar variabel yang memengaruhi hipotesis. Sedangkan pendekatan kuantitatif adalah pendekatan yang menghasilkan data dalam bentuk skor atau nilai atas jawaban yang diperoleh melalui kuesioner. Alasan utama pemilihan jenis penelitian eksplanatori yaitu untuk menguji hipotesis yang diajukan agar dapat menjelaskan pengaruh implementasi SIMDA, kinerja aparatur pemerintah daerah, dan penerapan SAP terhadap kualitas LKPD. Penelitian ini dilakukan pada seluruh OPD di Kabupaten Lombok Tengah.

Populasi adalah wilayah generalisasi yang terdiri atas objek atau subjek yang memiliki kualitas dan karakteristik tertentu yang diterapkan oleh peneliti untuk dipelajari dan kemudian ditarik kesimpulannya (Sugiyono, 2016:80). Populasi dalam penelitian ini adalah para aparatur pemerintah daerah subbagian keuangan dan perencanaan pada OPD di Kabupaten Lombok Tengah. Berdasarkan data yang diperoleh dari Sekretariat Daerah Pemerintah Kabupaten Lombok Tengah Tahun 2019 jumlah OPD di Kabupaten Lombok Tengah, yaitu sebanyak 32 OPD yang terdiri dari Dinas, Badan, Kantor dan Inspektorat. Sedangkan menurut Sugiyono (2016:85) sampel merupakan bagian dari jumlah dan/atau karakteristik yang dimiliki oleh populasi tersebut. Teknik pengambilan sampel penelitian ini dengan metode non probability sampling dengan pendekatan purposive sampling yaitu teknik pengambilan sampel berdasarkan sumber data dengan pertimbangan tertentu (Sugiyono, 2016:85). Purposive sampling ini digunakan karena informasi yang akan diambil berasal dari sumber yang sengaja 
dipilih berdasarkan pertimbangan atau kriteria tertentu yang harus dipenuhi oleh sampel yang menjadi objek dalam penelitian ini.. Adapun nama-nama OPD di Kabupaten Lombok Tengah yang dijadikan sampel dalam penelitian ini dapat dilihat pada Tabel 1 sebagai berikut:

Tabel 1.

Daftar Nama OPD di Kabupaten Lombok Tengah

\begin{tabular}{|c|c|c|}
\hline No. & Nama-Nama OPD & Responden \\
\hline 1. & Dinas Pendidikan & 3 Orang \\
\hline 2. & Dinas Pemuda dan Olahraga & 3 Orang \\
\hline 3. & Dinas Kesehatan & 3 Orang \\
\hline 4. & Dinas Pekerjaan Umum dan Penataan Ruang & 3 Orang \\
\hline 5. & Dinas Perumahan dan Kawasan Permukiman & 3 Orang \\
\hline 6. & Dinas Sosial & 3 Orang \\
\hline 7. & Dinas Tenaga Kerja dan Transmigrasi & 3 Orang \\
\hline 8. & Dinas Perhubungan & 3 Orang \\
\hline 9. & Dinas Kependudukan dan Catatan Sipil & 3 Orang \\
\hline 10. & Dinas Pariwisata dan Kebudayaan & 3 Orang \\
\hline 11. & Dinas Koperasi, Usaha Kecil Menengah & 3 Orang \\
\hline 12. & Dinas Perindustrian dan Perdagangan & 3 Orang \\
\hline 13. & Dinas Pertanian & 3 Orang \\
\hline 14. & Dinas Pemberdayaan Masyarakat dan Desa & 3 Orang \\
\hline 15. & Dinas Ketahanan Pangan & 3 Orang \\
\hline 16. & $\begin{array}{l}\text { Dinas Pemberdayaan Perempuan, Perlindungan Anak, Pengendalian } \\
\text { Penduduk dan Keluarga Berencana }\end{array}$ & 3 Orang \\
\hline 17. & Dinas Lingkungan Hidup & 3 Orang \\
\hline 18. & Dinas Penanaman Modal dan Pelayanan Terpadu Satu Pintu & 3 Orang \\
\hline 19. & Dinas Komunikasi dan Informatika & 3 Orang \\
\hline 20. & Dinas Perpustakan dan Kearsipan & 3 Orang \\
\hline 21. & Dinas Kelautan dan Perikanan & 3 Orang \\
\hline 22. & Badan Kesatuan Bangsa dan Politik & 3 Orang \\
\hline 23. & Badan Kepegawaian, Pendidikan dan Pelatihan & 3 Orang \\
\hline
\end{tabular}

Kriteria tertentu dari sampel tersebut adalah para aparatur yang melaksanakan fungsi penganggaran dan akuntansi dan terlibat langsung dalam implementasi SIMDA Keuangan pada OPD di Kabupaten Lombok Tengah. Sehingga sampel dalam penelitian ini adalah berjumlah 96 responden yang terdiri dari: kepala subbagian keuangan dan perencanaan, bendahara pengeluaran, dan staf subbagian keuangan dan perencanaan. 
Tabel 2.

Daftar Nama OPD di Kabupaten Lombok Tengah (lanjutan)

\begin{tabular}{|c|c|c|}
\hline No. & Nama-Nama OPD & Responden \\
\hline 24. & Badan Perencanaan, Penelitian dan Pengembangan Daerah & 3 Orang \\
\hline 25. & Badan Pengelolaan Keuangan dan Aset Daerah & 3 Orang \\
\hline 26. & Badan Pengelolaan Pendapatan Daerah & 3 Orang \\
\hline 27. & Badan Nasional Penganggulan Bencana Daerah & 3 Orang \\
\hline 28. & RSUD Praya & 3 Orang \\
\hline 29. & Sekretariat Daerah & 3 Orang \\
\hline 30 . & Sekretariat DPRD & 3 Orang \\
\hline 31. & Inspektorat & 3 Orang \\
\hline \multirow[t]{2}{*}{32.} & Satpol PP & 3 Orang \\
\hline & Jumlah & 96 Orang \\
\hline
\end{tabular}

Sumber: Data diolah, 2018

Variabel independen pada penelitian ini adalah implementasi SIMDA $\left(\mathrm{X}_{1}\right)$, kinerja aparatur pemerintah daerah $\left(\mathrm{X}_{2}\right)$, dan penerapan $\mathrm{SAP}\left(\mathrm{X}_{3}\right)$. implementasi SIMDA $\left(\mathrm{X}_{1}\right)$ dapat diukur dengan dua proksi, antara lain: perangkat, dan pengelolaan data keuangan (Ole, 2014, dimodifikasi). Kinerja aparatur pemerintah daerah $\left(\mathrm{X}_{2}\right)$ dapat diukur dengan menggunakan dua proksi, yaitu: proses, dan hasil (Oktarina, dkk., 2016, dimodifikasi). Serta penerapan SAP $\left(\mathrm{X}_{3}\right)$ dapat diukur dengan dua belas proksi, antara lain: PSAP 01 Penyajian Laporan Keuangan; PSAP 02 Laporan Realisasi Anggaran; PSAP 03 Laporan Arus Kas; PSAP 04 Catatan atas Laporan Keuangan; PSAP 05 Akuntansi persediaan; PSAP 06 Akuntansi Investasi; PSAP 07 Akuntansi Aset Tetap; PSAP 08 Akuntansi Konstruksi dalam Pengerjaa; PSAP 09 Akuntansi Kewajiban; PSAP 10 Koreksi kesalahan, perubahan Kebijakan akuntansi, perubahan estimasi Akuntansi, dan operasi yang tidak dilanjutkan; PSAP 11 Laporan Keuangan Konsolidasian; dan PSAP 12 Laporan Operasional (Peraturan Pemerintah Nomor 71 Tahun 2010, dimodifikasi). Sedangkan variabel dependen pada penelitian ini adalah kualitas LKPD yang dapat diukur dengan menggunakan empat proksi, yaitu: relevan, andal, dapat dibandingkan dan dapat dipahami (Peraturan 
Pemerintah Nomor 71 Tahun 2010; Ramadhan dan Rahayu, 2015, dimodifikasi). Pengujian terhadap implementasi SIMDA, kinerja aparatur pemerintah daerah, penerapan SAP, dan kualitas LKPD diukur dengan skala likert yang terdiri dari lima opsi sebagai berikut: sangat tidak setuju, tidak setuju, cukup setuju, setuju, dan sangat setuju (Sugiyono, 2015:93).

Alat analisis yang digunakan dalam penelitian ini adalah analisis regresi linier berganda dengan program SPSS versi 16, hal ini dilakukan untuk mengetahui pengaruh variabel independen terhadap variabel dependen. Namun, sebelum melakukan uji hipotesis terlebih dahulu menguji analisis kualitas data dengan uji validitas yang dilakukan untuk mengukur sah atau valid tidaknya suatu kuesioner, dan uji reliabilitas dilakukan untuk mengukur suatu kuesioner yang merupakan indikator dari variabel atau konstruk. Setelah itu, dilakukan uji asumsi klasik untuk memastikan bahwa dalam penelitian ini tidak terdapat multikolinearitas dan heteroskedastisitas, serta data yang dihasilkan dapat berdistribusi secara normal. Adapun model persamaan yang digunakan adalah sebagai berikut:

$$
Y=\alpha+b_{1} X_{1}+b_{2} X_{2}+b_{3} X_{3}+\varepsilon
$$

Keterangan:

$\mathrm{Y}=$ Kualitas LKPD

$\alpha=$ Intercept atau Konstanta

$\mathrm{b}=$ Koefisien Regresi

$\mathrm{X}_{1}=$ Implementasi SIMDA

$\mathrm{X}_{2}=$ Kinerja Aparatur Pemerintah Daerah

$\mathrm{X}_{3}=$ Penerapan SAP

$\varepsilon=$ error 


\section{HASIL DAN PEMBAHASAN}

Data pada penelitian ini dikumpulkan dengan menyebarkan kuesioner pada 32 OPD di Kabupaten Lombok Tengah dengan jumlah responden sebanyak 96 orang yang terdiri dari: kepala subbagian keuangan dan perencanaan, bendahara pengeluaran, dan staf subbagian keuangan dan perencanaan. Pendistribusian kuesioner dilakukan dalam kurun waktu \pm 4 minggu kepada aparatur pemerintah daerah yang menjadi objek penelitian, dimulai dari tanggal 12 Oktober 2018 sampai dengan 9 November 2018. Dari 96 kuesioner yang disebarkan, namun sebanyak 77 kuesioner yang dikembalikan atau sebesar 80,20\% dari total keseluruhan kuesioner telah disebar. Seluruh kuesioner yang dikembalikan dapat diolah karena terisi secara lengkap oleh responden. Adapun rincian penerimaan dan pengambalian kuesioner dapat dilihat pada Tabel 3 sebagai berikut:

Tabel 3. Rincian Penerimaan dan Pengembalian Kuesioner

\begin{tabular}{lc}
\hline \multicolumn{1}{c}{ Keterangan } & Jumlah \\
\hline Total Pengiriman Kuesioner & 96 \\
Kuesioner yang kembali & 77 \\
Kuesioner yang tidak kembali & 19 \\
Kuesioner yang tidak dapat digunakan & 0 \\
Total kuesioner yang digunakan & 77 \\
Tingkat pengembalian (response rate) $77 / 96 * 100 \%$ & $80,20 \%$ \\
\hline
\end{tabular}

Sumber: Data diolah, 2018

Jumlah responden $(\mathrm{N})$ pada penelitian ini sebanyak 77 responden, maka nilai diperoleh $r_{\text {tabel }}$ sebesar 0,22 . Hasil dari $r_{\text {tabel }}$ tersebut didapatkan dari Tabel $r$ (Pearson Product Moment). Angka $\mathrm{r}_{\text {tabel }}$ tersebut kemudian dibandingkan dengan nilai $r_{\text {hitung }}$ yang telah diketahui dari nilai output SPSS tiap variabel penelitian dengan ketentuan yaitu: jika $r_{\text {hitung }}>r_{\text {tabel }}$ maka variabel tersebut valid, dan jika $\mathrm{r}_{\text {hitung }}<\mathrm{r}_{\text {tabel }}$ maka variabel tersebut tidak valid. Berdasarkan hasil uji validitas 
semua item pertanyaan pada tiap variabel penelitian ini adalah valid. Hal ini dapat dilihat dari nilai $r_{\text {hitung }}$ masing-masing item yang lebih besar dari nilai $r_{\text {tabel. }}$.

Sedangkan untuk mengetahui reliabilitas dari kuesioner maka dapat ditentukan dari kriteria-kriterianya jika dilihat dari alpha $(\alpha)$ seperti yang dikemukakan oleh Hinton et al. (2004:364). Hasil uji reliabilitas masing-masing variabel dapat dilihat pada Tabel 4 berikut ini:

Tabel 4.

Hasil Uji Reliabilitas

\begin{tabular}{clcc}
\hline No. & \multicolumn{1}{c}{ Variabel } & Alpha $(\alpha)$ & Hasil \\
\hline 1. & Implementasi SIMDA $\left(\mathrm{X}_{1}\right)$ & 0,721 & Reliabilitas Tinggi \\
2. & Kinerja Aparatur Pemerintah Daerah $\left(\mathrm{X}_{2}\right)$ & 0,744 & Reliabilitas Tinggi \\
3. & Penerapan SAP $\left(\mathrm{X}_{3}\right)$ & 0,735 & Reliabilitas Tinggi \\
4. & Kualitas LKPD $(\mathrm{Y})$ & 0,710 & Reliabilitas Tinggi \\
\hline \multicolumn{2}{l}{ Sumber: }
\end{tabular}

Uji statistik yang digunakan untuk uji normalitas data dalam penelitian ini adalah Uji Kolmogorov-Smirnov (uji K-S) dengan tingkat signifikansi $\alpha=0,05$. Hasil tersebut berdasarkan kriteria probabilitas, yaitu: jika probabilitas $<0,05$ maka data tidak dapat berdistribusi normal, dan jika probabilitas $>0,05$ maka data dapat berdistribusi normal. Adapun hasil pengolahan data untuk uji normalitas pada penelitian ini dapat dilihat pada Tabel 5.

Tabel 5.

Hasil Uji Normalitas

\begin{tabular}{lc}
\hline \multicolumn{1}{c}{ Keterangan } & Unstandardized Residual \\
\hline $\mathrm{N}$ & 77 \\
Kolmogorov-Smirnov Z & 0,625 \\
Asymp. Sig. & 0,830 \\
\hline Sumber: Data diolah, 2018
\end{tabular}

Dari tampilan Tabel 5 menunjukkan nilai K-S sebesar 0,625 dengan nilai probabilitas $0,830>0,05$ maka dapat dikatakan bahwa data residual berdistribusi normal. Hal ini berarti hipotesis nol $\left(\mathrm{H}_{0}\right)$ diterima atau variabel tersebut 
terdistribusi secara normal.

Uji Multikolonieritas dapat dilihat dari nilai tolerance atau Variance Inflation Factor (VIF). Hasil output SPSS untuk uji multikolonieritas masingmasing variabel dapat dilihat pada Tabel 5. Berdasarkan Tabel 5 hasil perhitungan nilai tolerance menunjukkan bahwa tidak ada variabel independen yang memiliki nilai tolerance $<0,10$ yang berarti bahwa tidak ada korelasi antar variabel independen yang nilainya $>95 \%$. Selain itu, hasil pehitungan nilai Variance Inflation Factor (VIF) juga menunjukkan hal yang sama, yaitu tidak ada variabel independen yang memiliki nilai VIF > 10. Jadi, dapat disimpulkan bahwa tidak terjadi multikolonieritas antar variabel independen dalam model regresi penelitian ini.

Tabel 6. Hasil Uji Multikolonieritas

\begin{tabular}{lcc}
\hline \multicolumn{1}{c}{ Variabel } & Tolerance & VIF \\
\hline Implementasi SIMDA $\left(\mathrm{X}_{1}\right)$ & 0,438 & 2,284 \\
Kinerja Aparatur Pemerintah Daerah $\left(\mathrm{X}_{2}\right)$ & 0,399 & 2,506 \\
Penerapan SAP $\left(\mathrm{X}_{3}\right)$ & 0,615 & 1,627 \\
\hline Sumber: Data diolah, 2018 & &
\end{tabular}

Model regresi yang baik adalah tidak terjadi heteroskedastisitas. Penelitian ini menggunakan uji glejser dalam melakukan pengujian heteroskedastisitas. Hasil pengolahan data untuk uji glejser dalam pengujian heteroskedastisitas dapat dilihat pada Tabel 6. Berdasarkan Tabel 6 diketahui bahwa nilai signifikasi variabel implementasi SIMDA $\left(\mathrm{X}_{1}\right)$, kinerja aparatur pemerintah daerah $\left(\mathrm{X}_{2}\right)$, penerapan SAP $\left(\mathrm{X}_{3}\right)$ masing-masing adalah 0,$796 ; 0,582$ dan 0,635 . Hal ini menunjukkan bahwa ketiga variabel independen tersebut memiliki nilai signifikansi $>0,05$ artinya tidak terjadi heteroskedastisitas di ketiga variabel tersebut. 
Tabel 7.

Hasil Uji Glejser

\begin{tabular}{lcc}
\hline \multicolumn{1}{c}{ Variabel } & $\mathrm{t}$ & Sig. \\
\hline Implementasi SIMDA $\left(\mathrm{X}_{1}\right)$ & $-0,259$ & 0,796 \\
Kinerja Aparatur Pemerintah Daerah $\left(\mathrm{X}_{2}\right)$ & 0,552 & 0,582 \\
Penerapan SAP $\left(\mathrm{X}_{3}\right)$ & 0,477 & 0,635 \\
\hline
\end{tabular}

Sumber: Data diolah, 2018

Uji regresi linier berganda pada penelitian ini bertujuan untuk mengetahui ada tidaknya pengaruh implementasi SIMDA, kinerja aparatur pemerintah daerah, dan penerapan SAP terhadap kualitas LKPD dan apakah berpengaruh positif atau negatif. Adapun persamaan analisis regresi linier berganda yaitu:

$\mathrm{Y}=\alpha+\mathrm{b}_{1} \mathrm{X}_{1}+\mathrm{b}_{2} \mathrm{X}_{2}+\mathrm{b}_{3} \mathrm{X}_{3}+\varepsilon$

\section{Tabel 8.}

Uji Regresi Linier Berganda, Uji Signifikansi Parameter Individual, Uji Koefisien Determinan, dan Uji Signifikansi Simultan

\begin{tabular}{|c|c|c|c|c|c|c|c|}
\hline \multirow{2}{*}{$\begin{array}{c}\text { Variabel } \\
\text { Independen }\end{array}$} & \multicolumn{2}{|c|}{$\begin{array}{l}\text { Unstandardized } \\
\text { Coefficients }\end{array}$} & \multirow[b]{2}{*}{$\mathrm{t}$} & \multirow{2}{*}{ Sig. } & \multirow{2}{*}{ Adj. $R^{2}$} & \multirow{2}{*}{$\mathrm{F}$} & \multirow{2}{*}{ Ket. } \\
\hline & B & $\begin{array}{l}\text { Standar } \\
\text { Error }\end{array}$ & & & & & \\
\hline (Constant) & 19,492 & 4,075 & 4,784 & 0,000 & 13,140 & 0,324 & \\
\hline $\begin{array}{l}\text { Implementasi } \\
\text { SIMDA }\end{array}$ & 0,354 & 0,143 & 2,468 & 0,016 & & & Signifikan \\
\hline $\begin{array}{l}\text { Kinerja Aparatur } \\
\text { Pemerintah Daerah }\end{array}$ & 0,430 & 0,213 & 2,023 & 0,047 & & & Signifikan \\
\hline Penerapan SAP & $-0,024$ & 0,098 & $-0,030$ & 0,247 & & & $\begin{array}{l}\text { Tidak } \\
\text { Signifikan }\end{array}$ \\
\hline
\end{tabular}

Berdasarkan Tabel 8 dapat diperoleh rumus regresi linier berganda sebagai berikut:

$$
Y=19,492+0,354 X_{1}+0,430 X_{2}-0,024 X_{3}+\varepsilon
$$

Penjelasan dari rumus di atas yaitu: a) Jika semua variabel independen memiliki nilai nol (0) maka nilai variabel dependen sebesar 19,492; b) Nilai koefisien implementsi SIMDA $\left(\mathrm{X}_{1}\right)$ sebesar 0,354 dan bertanda positif. Hal ini menunjukkan bahwa koefisien implementsi SIMDA memiliki hubungan yang 
searah dengan kualitas LKPD, sehingga mengandung arti jika implementsi SIMDA meningkat maka kualitas LKPD (Y) akan meningkat pula sebesar 0,354 dengan asumsi bahwa variabel independen yang lain dari model regresi linier berganda tersebut adalah konstan atau tetap; c) Nilai koefisien kinerja aparatur pemerintah daerah $\left(\mathrm{X}_{2}\right)$ sebesar 0,430 dan bertanda positif. Hal ini menunjukkan bahwa koefisien kinerja aparatur pemerintah daerah memiliki hubungan yang searah dengan kualitas LKPD, sehingga mengandung arti jika kinerja aparatur pemerintah daerah meningkat maka akan meningkatkan kualitas LKPD juga sebesar 0,430 dengan asumsi bahwa variabel independen yang lain dari model regresi linier berganda tersebut adalah konstan atau tetap; d) Nilai koefisien penerapan SAP $\left(\mathrm{X}_{3}\right)$ sebesar 0,024 dan bertanda negatif. Hal ini menunjukkan bahwa koefisien penerapan SAP memiliki hubungan yang berlawanan arah dengan kualitas LKPD, sehingga mengandung arti jika penerapan SAP meningkat maka kualitas LKPD akan menurun sebesar 0,024 dengan asumsi bahwa variabel independen yang lain dari model regresi linier berganda tersebut adalah konstan atau tetap.

Serta untuk mengetahui seberapa besar variabel kualitas LKPD dipengaruhi oleh implementasi SIMDA, kinerja aparatur pemerintah daerah, dan penerapan SAP dapat dilihat pada Tabel 7. Dari Tabel 7 menunjukkan bahwa besarnya nilai Adj. $\mathrm{R}^{2}=0,324$. Hal ini berarti sebesar $32,4 \%$ variasi kualitas LKPD dapat dijelaskan oleh implementasi SIMDA, kinerja aparatur pemerintah daerah, dan penerapan SAP. Sedangkan sisanya $(100 \%-32,4 \%=67,4 \%)$ dijelaskan oleh faktor lain yang tidak diteliti dalam penelitian ini. 
Untuk mengetahui apakah semua variabel independen pada penelitian ini memiliki pengaruh secara simultan terhadap variabel dependennya, maka dilakukan uji statistik F (uji F). Nilai $F_{\text {tabel }}$ diperoleh dengan menggunakan tabel F dengan degree of freedom (df) yaitu ( $\mathrm{N}$ - k) sebagai df penyebut dan df regression yaitu ( $\mathrm{k}-1)$ sebagai df pembilang dengan tingkat signifikansi $\alpha=0,05$. Dimana, $\mathrm{N}$ adalah jumlah responden, dan $\mathrm{k}$ adalah jumlah variabel baik variabel independen maupun variabel dependen. Hasil pengujian signifikansi simultan (uji statistik F) dapat dilihat pada Tabel 7.

Dari uji ANOVA atau F pada Tabel 7 diperoleh nilai $F_{\text {hitung }}$ sebesar 13,140 dengan Sig $F=0,000$, sedangkan nilai $F_{\text {tabel }}$ sebesar 2,72. Jadi, dapat disimpulkan bahwa $F_{\text {hitung }}>F_{\text {tabel }}(13,140>2,72)$ atau Sig $\mathrm{F}<5 \%(0,000<0,05)$ sehingga $\mathrm{H}_{0}$ ditolak dan $\mathrm{H}_{1}$ diterima. Hal ini berarti bahwa implementasi SIMDA, kinerja aparatur pemerintah daerah, dan penerapan SAP secara simultan memiliki pengaruh yang signifikan dengan kualitas LKPD.

Untuk menguji hipotesis secara signifikan digunakan uji t, yaitu untuk menguji pengaruh variabel independen terhadap variabel dependen secara signifikan yang didasarkan pada nilai signifikansi masing-masing variabel dengan $\alpha=0,05$. Apabila nilai Sig. $<0,05$ maka $H_{1}$ dapat diterima yang menyatakan bahwa suatu variabel independen secara signifikan mempengaruhi variabel dependen. Hasil pengolahan data untuk uji t dapat dilihat pada Tabel 7.

Berdasarkan hasil Tabel 7 dapat dijelaskan sebagai berikut: a) Hasil penelitian dari pengujian hipotesis pertama $\left(\mathrm{H}_{1}\right)$ untuk variabel implementasi SIMDA $\left(\mathrm{X}_{1}\right)$ menunjukkan bahwa variabel $\mathrm{X}_{1}$ memiliki $\mathrm{t}_{\text {hitung }}$ lebih besar dari $\mathrm{t}_{\text {tabel }}$ 
atau nilai 2,468 $>1,665$ dengan nilai signifikan di atas $\alpha=0,05$ atau nilai $0,016<$ 0,05 maka $\mathrm{H}_{0}$ ditolak dan $\mathrm{H}_{1}$ diterima. Artinya, implementasi SIMDA berpengaruh secara signifikan terhadap kualitas LKPD dan nilai $\mathrm{t}_{\text {hitung }}$ positif menunjukkan bahwa implementasi SIMDA memiliki hubungan yang searah dengan kualitas LKPD. Hasil pengujian hipotesis tersebut didukung oleh penelitian yang dilakukan Xu dan Lu (2003), Salehi et al. (2010), Grande et al. (2011), Ole (2014), serta Kamal dan Noermansyah (2015). Sedangkan hasil deskripsi variabel penelitian atas pengisian kuesioner yang dilakukan oleh responden menunjukkan bahwa responden telah mengimplementasi SIMDA dengan baik, hal ini dikarenakan oleh: perangkat yang digunakan responden dalam mengimplementasikan SIMDA mudah digunakan, jaringan internet telah terpasang dan dimanfaatkan sebagai penghubung antar unit kerja dalam pengiriman data dan informasi yang dibutuhkan, responden dalam membuat LKPD telah dibantu dengan aplikasi SIMDA Keuangan, pengolahan data transaksi keuangan menggunakan SIMDA Keuangan telah digunakan dengan baik dan benar sesuai dengan peraturan perundang-undangan, serta implementasi SIMDA telah menciptakan efisiensi dan efektivitas pada pekerjaan responden. Sehingga dapat dikatakan bahwa implementasi SIMDA memiliki pengaruh terhadap kualitas LKPD tersebut; b) Hasil penelitian dari pengujian hipotesis kedua $\left(\mathrm{H}_{2}\right)$ untuk variabel kinerja aparatur pemerintah daerah $\left(\mathrm{X}_{2}\right)$ menunjukkan bahwa variabel $\mathrm{X}_{2}$ memiliki $\mathrm{t}_{\text {hitung }}$ lebih besar dari $\mathrm{t}_{\text {tabel }}$ atau nilai 2,023>1,665 dengan nilai signifikan di atas $\alpha=0,05$ atau nilai $0,047<0,05$ maka $\mathrm{H}_{0}$ ditolak dan $\mathrm{H}_{1}$ diterima. Artinya, kinerja aparatur pemerintah daerah berpengaruh secara 
signifikan terhadap kualitas LKPD dan nilai $t_{\text {hitung }}$ positif menunjukkan bahwa kinerja aparatur pemerintah daerah memiliki hubungan yang searah dengan kualitas LKPD. Hal ini didukung oleh penelitian yang dilakukan Ramadhan dan Rahayu (2015), serta Oktarina, dkk. (2016). Sedangkan hasil deskripsi variabel penelitian atas pengisian kuesioner yang dilakukan oleh responden menunjukkan bahwa responden telah memiliki kinerja yang baik, hal ini dikarenakan oleh: responden tiba di kantor tepat waktu sesuai dengan ketentuan jam kerja yang berlaku dan memanfaatkan jam kerja secara efektif dan efisien, melalui kerja sama yang baik antar pegawai telah mampu menyelesaikan permasalahan yang dihadapi responden dalam pekerjaannya, prestasi kerja responden merupakan perilaku yang nyata dalam meningkatkan kinerjanya, serta kuantitas kinerja responden telah sesuai dengan standar kerja yang ditentukan. Sehingga dapat dikatakan bahwa kinerja aparatur pemerintah daerah memiliki pengaruh terhadap kualitas LKPD tersebut; c) Hasil penelitian dari pengujian hipotesis ketiga $\left(\mathrm{H}_{3}\right)$ untuk variabel penerapan $\mathrm{SAP}\left(\mathrm{X}_{3}\right)$ menunjukkan bahwa variabel $\mathrm{X}_{3}$ memiliki $\mathrm{t}_{\text {hitung }}$ lebih kecil dari $\mathrm{t}_{\text {tabel }}$ atau nilai $-0,030<1,665$ dengan nilai signifikan di bawah $\alpha=0,05$ atau nilai 0,247>0,05 maka $\mathrm{H}_{0}$ diterima dan $\mathrm{H}_{1}$ ditolak. Artinya, penerapan SAP tidak memiliki pengaruh secara signifikan terhadap kualitas LKPD dan nilai $t_{\text {hitung }}$ positif menunjukkan bahwa penerapan SAP memiliki hubungan yang searah dengan kualitas LKPD. Hasil pengujian hipotesis tersebut tidak konsisten dengan hasil penelitian yang dilakukan Sari (2013), Ahsani (2015), Ramadhan dan Rahayu (2015), Oktarina, dkk. (2016), serta Yusniyar, dkk. (2016). Sedangkan hasil deskripsi variabel penelitian atas pengisian 
kuesioner yang dilakukan oleh responden menunjukkan bahwa penerapan SAP pada OPD di Kabupaten Lombok tengah telah baik, hal ini dikarenakan dalam membuat LKPD responden harus berpedoman pada SAP yang terdiri dari: PSAP 01 tentang Penyajian Laporan Keuangan, PSAP 02 tentang Laporan Realisasi Anggaran, PSAP 03 tentang Laporan Arus Kas, PSAP 04 tentang Catatan atas Laporan Keuangan, PSAP 05 tentang Akuntansi persediaan, PSAP 06 tentang Akuntansi Investasi, PSAP 07 tentang Akuntansi Aset Tetap, PSAP 08 tentang Akuntansi Konstruksi dalam Pengerjaa, PSAP 09 tentang Akuntansi Kewajiban, PSAP 10 tentang Koreksi kesalahan, perubahan Kebijakan akuntansi, perubahan estimasi Akuntansi, dan operasi yang tidak dilanjutkan, PSAP 11 tentang Laporan Keuangan Konsolidasian, serta PSAP 12 tentang Laporan Operasional. Sehingga dengan diwajibkan berpedoman pada SAP dalam pembuatan LKPD, responden menganggap bahwa penerapan SAP tidak memiliki pengaruh kepada responden dalam kualitas LKPD.

\section{SIMPULAN}

Berdasarkan uraian dan analisa yang telah dilakukan pada 32 OPD di Kabupaten Lombok Tengah, maka dapat ditarik kesimpulan yaitu: implementasi SIMDA yang telah dilakukan oleh seluruh OPD di Kabupaten Lombok Tengah memiliki dampak positif kepada responden dalam menghasilkan LKPD yang berkualitas dan akuntabel. Artinya, walaupun pada saat awal penguasaan pengoperasian SIMDA yang belum merata di setiap OPD dan dirasakan sulit oleh para pengguna, namun dengan berjalannya waktu pengguna aplikasi SIMDA dapat 
merasakan dampak positif yang dapat memudahkan mereka dalam menyusun LKPD secara efektif dan efisien. Hal ini juga dapat membantu pengguna dalam meningkatkan kinerjanya. Dengan meningkatnya kinerja aparatur pemerintah daerah yang selaku pengguna dari aplikasi SIMDA tersebut, maka LKPD yang dihasilkan akan berkualitas pula. Hal ini telah dibuktikan dengan pemberian opini WTP oleh BPK atas LKPD yang dihasilkan oleh Pemerintah Daerah Kabupaten Lombok Tengah dua tahun terakhir ini. Akan tetapi dalam penerapan SAP, OPD di Kabupaten Lombok Tengah tidak memengaruhi kualitas LKPD. Hal ini dikarenakan SAP dalam penyusunan LKPD telah diwajibkan untuk diterapkan sehingga aparatur pemerintah daerah tidak merasakan dampak yang signifikan terhadap kualitas LKPD tersebut.

Dari hasil penelitian yang telah diuraikan di atas, maka disarankan bagi penelitian selanjutnya dapat memerluas sampel penelitian dengan melakukan penelitian pada OPD di kota dan/atau kabupaten lainnya, serta dapat menambahkan variabel-variabel lain yang diduga berpengaruh terhadap kualitas LKPD, misalnya good governance, kompetensi sumber daya manusia, sistem pengendalian intern, dan lain-lain.

\section{REFERENSI}

Ahsani, Irvan. (2015). Penerapan Standar Akuntansi Pemerintahan, Kompetensi Sumber Daya Manusia, dan Sistem Pengendalian Internal Serta Pengaruhnya Terhadap Kualitas Laporan Keuangan Satuan Kerja Perangkat Daerah (Studi Pada SKPD Di Kabupaten Kotawaringin Barat, Kalimantan Tengah). Journal of Muhamadiyah Yogyakarta University.

Baron, R. M. and Kenny, D. A. (1986). The Moderator-Mediator Variable Distinction in Social Psychological Research: Conceptual, Strategic, and 
Statistical Considerations. Journal of Personality and Social Psychology, 51(6), 1173-1182.

Bastian, Indra. (2010). Akuntansi Sektor Publik di Indonesia. Yogyakarta: BPFE.

Basuki, Agus Tri. (2018). Pengantar Ekonometrika (Dilengkapi Penggunaan Eviews). Yogyakarta: Katalog Dalam Terbitan (KDT).

Baswir, Revrisond. (2000). Akuntansi Pemerintahan Indonesia. Yogyakarta: BPFE.

Davis, Fred D. (1989). Perceived Usefulness, Perceived Ease of Use, and User Acceptance of Information Technology. MIS Quarterly Vol. 13 No. 3: 319339.

Dhiyavani, Siti Indah. (2017). Pengaruh Kinerja Aparatur Pemerintah Daerah, PengelolaanKeuangan Daerah, Sistem Pengendalian Internal, dan Implementasi Standar Akuntansi Pemerintah Terhadap Penerapan Good government governance. JOM Fekon Vol. 4 No. 1: 1859-1872.

Ghozali, Imam. (2011). Aplikasi Analisis Multivariate Dengan Program IBM. SPSS 19 (edisi kelima). Semarang: Badan Penerbit Universitas Diponegoro. . (2013). Aplikasi Analisis Multivariate dengan Program SPSS. Edisi Ketujuh. Semarang: Badan Penerbit Universitas Diponegoro.

Goldberg, Lewis R. (1965). Grade as Motivants. Psychology in the Schools 2: 1724.

Grande, Elena Urquía et al. (2011). The Impact of Accounting Information Systems (AIS) on Performance Measures: Empirical Evidence in Spanish SMEs. The International Journal of Digital Accounting Research Vol. 11: $25-43$.

Harahap, Sofyan Syafri. (2009). Analisis Kritis atas Laporan Keuangan. Jakarta: Raja Grafindo Persada.

Hinton, P. R., Brownlow, C., McMurray, I. and Cozens B. (2004). SPSS Explained. East Sussex: Routledge.

Imhoff, Eugene A. (2003). Accounting Quality, Auditing, and Corporate Governance. Accounting Horizons Journal Supplement: 117-128.

Jogiyanto, HM. (2007). Sistem Informasi Keperilakuan. Yogyakarta: Andi Publisher.

Kamal, Bahri. dan Noermansyah, Asrofi Langgeng. (2015). Analisis Faktor Yang 
Mempengaruhi Implemetasi SIMDA dan Kualitas Laporan Keuangan Pada SKPD. Jurnal of Politeknik Harapan Bersama Tegal.

Kuncoro, E.A dan Riduan. (2007). Cara Menggunakan dan Memakai Analisis Jalur (Path Analysis). Bandung: Alfabeta.

LAN. (2000). Akuntabilitas dan Good government governance, Modul I. Jakarta: Erlangga.

Mahmudi. (2015). Manajemen Kinerja Sektor Publik. Yogyakarta: Sekolah Tinggi Ilmu Manajemen YKPN.

Mangkunegara, A.A. Anwar Prabu. (2007). Manajemen Sumber Daya Manusia, Cetakan Ketujuh. Bandung: PT. Remaja Rosdakarya.

Mardiasmo. (2002). Akuntansi Sektor Publik. Yogyakarta: Andi. (2009). Akuntansi Sektor Publik. Yogyakarta: Andi.

Nugraeni dan Budiantara M. (2015). Pengaruh Standar Akuntansi Pemerintah Terhadap Kualitas Laporan Keuangan Dan Implikasinya Terhadap Akuntabilitas Kinerja. Jurnal Dinamika Ekonomi \& Bisnis Vol. 12, No. 1: 18-32.

Oktarina, Mia, dkk. (2016). Pengaruh Penerapan Standar Akuntansi Pemerintahan, Kualitas Aparatur Pemerintah Daerah dan Good Governance Terhadap Kualitas Laporan Keuangan di Kota Semarang (Studi Kasus pada Dinas Pengelolaan Keuangan Aset Daerah Kota Semarang Tahun 2014). Journal of Accounting, Vol. 2 No. 2.

Ole, H.R. (2014). Analisis Implementasi Sistem Informasi Manajemen Daerah (SIMDA) Terhadap Kualitas Laporan Keuangan SKPD (Studi Kasus Pada Dinas PPKAD Kabupaten Minahasa Tenggara). Jurnal Accountability Publisher: Accountability Vol. 3, No. 2.

Pardede, R. dan Manurung, R. (2014). Analisis Jalur Teori dan Aplikasi dalam Riset Bisnis. Jakarta: Penerbit PT Rineka Cipta.

Pulungan, M.S. (2014). Optimalisasi SIMDA dalam Mewujudkan Pengelolaan Keuangan Daerah Kabupaten Kutai Kartanegara Provinsi Kalimantan Timur yang Lebih Berkualitas. Bina Praja Journal: 269-282.

Ramadhan, Asra. dan Rahayu, Sri. (2015). Pengaruh Penerapan Standar Akuntansi, Kualitas Aparatur Terhadap Kualitas Laporan Keuangan (Studi Kasus Pada Biro Keuangan Provinsi Jawa Barat). Jurnal Eproc Telkom University: 1-7. 
Republik Indonesia. (2000). Peraturan Pemerintah Republik Indonesia Nomor 101 tentang Pendidikan dan Pelatihan Jabatan Pegawai Negeri Sipil. Jakarta: Sekretariat Negara.

(2003). Undang-Undang Nomor 17 tentang Keuangan Negara. Jakarta: Sekretariat Negara.

(2004). Undang-Undang Nomor 1 tentang Perbendaharaan Negara. Jakarta: Sekretariat Negara.

(2004a). Undang-Undang Nomor 15 tentang Pemeriksaan Pengelolaan dan Tanggung Jawab Keuangan Negara. Jakarta: Sekretariat Negara.

(2004b). Undang-Undang Nomor 32 tentang Pemerintahan Daerah. Jakarta: Sekretariat Negara.

(2005). Peraturan Pemerintah Nomor 24 tentang Standar Akuntansi Pemerintahan (SAP). Jakarta: Sekretariat Negara.

(2010). Peraturan Pemerintah No 71 tentang Standar Akuntansi Pemerintahan. Jakarta: Sekretariat Negara.

Rizki, L.N. (2012). Penatausahaan Asset pemerintah Daerah MelaluiSistem Informasi Manajemen Barang Daerah (SIMBADA) di Kabupaten Malang. Journal of Public Administration Research (JOPAR), Vol 1, No.1: 91-99.

Salehi, Mahdi et al. (2010). Usefulness of Accounting Information System in Emerging Economy: Empirical Evidence of Iran. International Journal of Economics and Finance, Vol. 2, No. 2: 186-195.

Santoso, Singgih. (2012). Statistik Parametik. Jakarta: PT Gramedia Pustaka.

Sari, Diana. (2013). Pengaruh Sistem Pengendalian Intern Pemerintah, Implementasi Standar Akuntansi Pemerintahan, Penyelesaian Temuan Audit Terhadap Kualitas Laporan Keuangan Pemerintah Daerah dan Implikasinya Terhadap Penerapan Prinsip-Prinsip Tata Kelola Pemerintahan yang Baik (Penelitian Pada Pemerintah Daerah di Provinsi Jawa Barat dan Banten). Indonesian Journal of Economics and Business: 166-124.

Sedarmayanti. (2012). Good government governance (Kepemerintahan Yang Baik) Membangun Sistem Manajemen Kinerja guna Meningkatkan Produktivitas Menuju Good government governance. Bandung: Mandar Maju.

Sekaran, Uma. (2007). Metodologi Penelitian untuk Bisnis. Jakarta: Salemba 
Empat.

Sloan, R.G. (2001). Financial Accounting and Corporate Governance: a Discussion. Journal of Accounting and Economics 32: 335-347.

Sugiyono. (2012). Metode Penelitian Kuantitatif, Kualitatif dan R\&D. Bandung: Alfabeta.

Aflabeta.

(2015). Metode Penelitian Kuantitatif Kualitatif $R \& B$. Bandung: (2016). Metode Penelitian Kuantitatif, Kualitatif, dan R\&D. Bandung: Alfabeta.

Waspodo, Lego. (2014). Pengaruh Implementasi Software Akuntansi Terhadap Kinerja Pegawai: Perceived Enjoyment dan Computer Playfulness Sebagai Variabel Moderating. Jurnal Manajemen dan Bisnis, Vol. 5. No. 2.

Widodo, Joko. (2006). Membangun Birokrasi Berbasis Kinerja. Jakarta: Bayumedai Publishing.

Xu, Hongjiang. dan Lu, Dandong. (2003). The Critical Success Factors For Data Quality In Accounting Information System-Different Industries' Perspective. IACIS Journal: 762-768. 